\title{
Failure of spleen cell migration assays to detect cell-mediated immunity to spermatozoa after natural mating in female mice*
}

\author{
S. Faruki and R. J. T. Hancock \\ Division of Immunology, National Institute for Medical Research, Mill Hill, London NW7 IAA, \\ U.K.
}

\begin{abstract}
Summary. We have re-examined whether immunity to spermatozoa can be detected by spleen cell migration assays in inseminated female mice. Unlike previous results, however, sperm suspensions inhibited the migration of splenic leucocytes obtained from mated as well as control mice. Small differences were observed between leucocytes from untreated virgin mice and leucocytes from mice immunized with spermatozoa in adjuvant. In these experiments lymph node cells draining the injection site were added to the spleen cells.
\end{abstract}

\section{Introduction}

Although spermatozoa carry a variety of antigens which are foreign to the female mammal, insemination of sperm cells at mating does not normally provoke sterilizing anti-sperm immunity (see e.g. Edwards, 1960). However, more limited immune responses may be provoked. Repeated mating in the absence of pregnancy has been reported to increase the tolerance of female mice to male skin grafts (Prehn, 1960; Lengerova \& Vojtiskova, 1963). Natural mating of surgically sterilized female mice to males of a different inbred strain has been reported to cause enlargement of the draining lymph nodes (Beer, Billingham \& Scott, 1975) and of the thymus (A. G. Clarke, personal communication). It has also been suggested (McLean, Shaya \& Gibbs, 1980) that the plasma cell proliferation observed in the uterine regional lymph nodes of rats within 2 days of outbred mating is provoked by the ejaculate. These limited immune responses to insemination and the factors regulating them are of interest because of their relevance to (a) the aetiology of the pathological anti-sperm immunity which apparently contributes to subfertility in some females (see Menge, 1980; Hancock, 1981, for reviews) and (b) mechanisms of immunological defence against infections of the reproductive tract. An in-vitro assay which detected anti-sperm immunity resulting from natural mating in females would be very valuable in such investigations and Dorsman, Tumboh-Oeri \& Roberts (1978) and Roberts \& Lewins (1979) reported that cellmediated immunity to spermatozoa in naturally mated females could be detected by leucocyte adherence and spleen cell migration assays. The rationale of cell migration assays is that when lymphocytes encounter an antigen to which they have been sensitized by previous exposure, they release factors which inhibit migration by the cells surrounding them. These assays have been traditionally applied to peripheral blood leucocytes in man (e.g. Bendixen \& Søborg, 1969) and peritoneal exudate cells in experimental animals (e.g. Bloom \& Bennett, 1966), although the use of other cell populations, including spleen cells (e.g. Hughes, Preece \& Light, 1980), has been reported. In this study we attempted to confirm the findings of Dorsman et al. (1978) and

* Reprint requests to Dr R. J. T. Hancock. 
investigated whether spleen cell migration procedures do provide assays that are sensitive enough to detect cell-mediated immunity to spermatozoa in mated mice.

\section{Materials and Methods}

Mice. Virgin female mice (strains A/J, DBA/2 and CBA $\times \mathrm{BALB} / \mathrm{c}$ ) were obtained from the SPF breeding unit at the National Institute for Medical Research, Mill Hill, where males and females are separated at 3 weeks of age.

Females were mated to males of the same inbred strain. Implantation was prevented by injecting the females with 2 i.u. PMSG (Dorsman et al., 1978). Virgin female controls were also injected with PMSG. Some female mice were immunized by subcutaneous injections at the base of the tail of $20 \times 10^{6}$ spermatozoa in Freund's complete adjuvant (Difco, E. Molesey, Surrey, U.K.), and, when spleen cells from these mice were tested, cells from lymph nodes draining the injection site were added to the spleen cells with the aim of increasing the numbers of antigen-reactive cells in the mixture (Alkan, 1978). Similar procedures were carried out on the control mice in these experiments.

Diluents. Hank's balanced salt solution (BSS), calcium- and magnesium-free Hank's balanced salt solution and Eagle's basal medium (EBM) with Hank's salts (Gibco Europe, Paisley, U.K.) were used.

Spermatozoa. Spermatozoa from the vas deferens and epididymides were washed 3 times in Hanks BSS, resuspended in Eagle's basal medium containing $15 \%$ fetal calf serum (FCS) and stored frozen at $-20^{\circ} \mathrm{C}$.

Migration inhibition tests. These were carried out essentially as described by Dorsman et al. (1978). When the results differed markedly from those of Dorsman et al. (1978) in that the in-vitro migration of spleen cells from virgin mice was strikingly inhibited by spermatozoa, some minor modifications based on procedures described by other workers (Bendixen \& Søborg, 1969, 1970; Federlin, Maini, Russell \& Dumonde, 1971; Maini, Roffe, Magrath \& Dumonde, 1973) were used, but the inhibition was not prevented.

Mice were killed and spleens removed into Hank's BSS 7-25 days after mating or injection because Roberts \& Lewins (1979) reported that cell-mediated immunity to spermatozoa was detectable from 4 to 50 days after mating. The spleens were disrupted by passage through a wire mesh. In all experiments the leucocytes were adjusted to $7 \times 10^{7} / \mathrm{ml}$ in EBM $+15 \%$ FCS and the cell suspension was drawn by capillary action into $10 \mu \mathrm{l}$ capillary tubes (Microcaps: Drummond Scientific, Broomall, Pennsylvania) which were then plugged at one end with a $1: 1(\mathrm{w} / \mathrm{w}) \mathrm{mixture}$ of paraffin wax and petroleum jelly. The tubes were centrifuged in batches of 8 , cut at the cell pellet; medium interface and the portions of the capillaries containing the cells laid flat in the wells of leucocyte migration plates (Sterilin, Teddington, Middlesex) or wells made from glass slides and Perspex. A spot of silicone grease was used to stick the capillaries to the bases of the wells. EBM + $15 \%$ FCS ( $\mathrm{pH} \mathrm{7 \cdot 3)} \mathrm{was} \mathrm{added} \mathrm{to} \mathrm{the} \mathrm{wells,} \mathrm{and} \mathrm{the} \mathrm{wells} \mathrm{sealed} \mathrm{with} \mathrm{coverslips} \mathrm{and} \mathrm{silicone} \mathrm{grease.}$ The plates were incubated at $37^{\circ} \mathrm{C}$ for up to $21 \mathrm{~h}$. At the end of the incubation, when the cells had migrated from the tube to form a fan, the plate was placed in a photographic enlarger, and the outline of the enlarged image of the fan traced. The area of this image was estimated by weighing.

All experiments used appropriate sterile techniques, and culture media containing antibiotics $(0.06 \mathrm{~g}$ penicillin $/ 1$ and $0.1 \mathrm{~g}$ streptomycin $/ \mathrm{l})$.

Leucocytes were separated from red cells either by Ficoll/Hypaque $(7 \mathrm{ml}$ cell suspension layered onto $3 \mathrm{ml}$ Ficoll-Paque (Pharmacia, Uppsala, Sweden), centrifuged $30 \mathrm{~min}$ at $500 \mathrm{~g}$ and the leucocytes removed from the Hank's BSS/Ficoll interface) by ammonium chloride lysis, or by settling under gravity (spleen cells resuspended in RPMI 1640 (Gibco) supplemented with 15\% FCS and left for $1 \mathrm{~h}$ in a gassed incubator $\left(6 \% \mathrm{CO}_{2}, 94 \%\right.$ air)). Leucocytes were washed 3 times (centrifuging at $450 \mathrm{~g}$ for $5 \mathrm{~min}$ ). Siliconized glassware was used in experiments with leucocytes prepared by settling under gravity or ammonium chloride lysis. 


\section{Results}

The in-vitro migration of leucocytes was inhibited by the presence of spermatozoa ( 24 different preparations used) and no significant differences between virgin and mated mice were detected by spleen cell migration assays. The results obtained with $\mathrm{A} / \mathrm{J}$ and $\mathrm{CBA} \times \mathrm{BALB} / \mathrm{c}$ mice are summarized in Table 1 . The $\mathrm{A} / \mathrm{J}$ spleen cells were depleted of red cells by ammonium chloride treatment, and the migration procedure was carried out on glass slides. In each experiment spleen cells were obtained from 1 mouse and 4 replicate capillary tubes packed with leucocytes were set up for each sperm concentration, giving a total of 16 tubes/mouse/experiment. The CBA $\times$ BALB/c splenic leucocytes were prepared by Ficoll/Hypaque centrifugation from 1 or 2 mice and 4-6 replicate tubes were set up for each sperm concentration. The migration procedure was carried out in Sterilin migration trays. In total 9 virgin and 9 mated CBA $\times$ BALB/c were used in the experiments summarized in Table 1 . Similar results were obtained with DBA $/ 2$ mice ( 5 virgin mice compared with 7 mated mice by the same methods used for the $\mathrm{A} / \mathrm{J}$ mice). No significant differences were observed between virgin and mated mice in the degree of inhibition of spleen cell migration caused by spermatozoa. Inhibition of migration greater than $20 \%$ by sperm concentrations as low as $1 \times 10^{6} / \mathrm{ml}$ was observed in $4 / 5$ experiments in which leucocytes from virgin DBA/2 mice were tested.

Inhibition of in-vitro migration of spleen cells obtained from virgin mice was also observed when medium without fetal calf serum was used. In 3 experiments using the same procedure as used for $\mathrm{A} / \mathrm{J}$ and DBA/ 2 mice in which the effects of spermatozoa $\left(10 \times 10^{6} / \mathrm{ml}\right)$ were compared for the migration of virgin spleen cells in media with and without added fetal calf serum, the mean $( \pm$ s.e.) $\%$ migration in medium containing fetal calf serum was $64.7 \%( \pm 9.6 \%)$ and in medium without fetal calf serum was $59 \%( \pm 4 \cdot 04 \%)$.

Inhibition of in-vitro migration of spleen cells obtained from virgin mice was observed whether Hank's BSS or calcium- and magnesium-free Hank's BSS were used for washing cells and was observed on siliconized and non-siliconized glass slides. In 3 experiments in which the effects of spermatozoa $\left(10 \times 10^{6} / \mathrm{ml}\right)$ on spleen cell migration on siliconized and non-siliconized glass slides were compared the mean ( \pm s.e.) $\%$ migration was $38.7 \%( \pm 9.3 \%$ ) on siliconized slides and $36 \%$ $( \pm 4 \cdot 7 \%)$ on non-siliconized slides.

Table 1. In-vitro migration $\dagger$ of splenic leucocytes from $A / J$ and $(C B A \times B A L B / c) F 1$ mice in the presence of spermatozoa

\begin{tabular}{|c|c|c|c|c|}
\hline \multirow{2}{*}{$\begin{array}{l}\text { Mouse } \\
\text { strain }\end{array}$} & \multirow{2}{*}{$\begin{array}{l}\text { Leucocyte } \\
\text { source }\end{array}$} & \multicolumn{3}{|c|}{ Sperm concentration $\left(\times 10^{-6} / \mathrm{ml}\right)$} \\
\hline & & 1 & 5 & 10 \\
\hline $\mathrm{A} / \mathbf{J}$ & $\begin{array}{l}\text { Virgin females } \\
\text { Females mated once }\end{array}$ & $\begin{array}{r}84.8 \pm 9.9 \\
82 \pm 8.4\end{array}$ & $\begin{array}{r}68.8 \pm 8.0 \\
65 \pm 8.0\end{array}$ & $\begin{array}{l}54 \cdot 0 \pm 4 \cdot 1 \\
57 \cdot 2 \pm 12 \cdot 5\end{array}$ \\
\hline $\begin{array}{l}(\mathrm{CBA} \times \mathrm{BALB} / \mathrm{c}) \\
\mathrm{F} 1\end{array}$ & $\begin{array}{l}\text { Virgin females } \\
\text { Females mated once } \\
\text { Virgin females } \\
\text { Virgin females } \\
\text { immunized with spermatozoa in Freund's } \\
\text { complete adjuvant }\end{array}$ & $\begin{array}{r}69 \pm 11 \cdot 2 \\
80.6 \pm 1 \cdot 6 \\
94.8 \pm 10 \cdot 8 \\
84.2 \pm 11 \cdot 1\end{array}$ & $\begin{array}{l}42 \cdot 6 \pm 5 \cdot 3 \\
48 \cdot 8 \pm 6 \cdot 1 \\
69 \cdot 5 \pm 10 \\
47 \cdot 2 \pm 5 \cdot 6\end{array}$ & $\begin{array}{r}32.5 \pm 4.9 \\
41 \pm 3.7 \\
54.3 \pm 7.9 \\
28.2 \pm 5.2^{*}\end{array}$ \\
\hline
\end{tabular}

area of migration in presence of spermatozoa

$\dagger$ Results expressed as:

area of migration in medium alone

Values are mean \pm s.e.m. for 5 or 6 experiments (A/J mice) or 4 or 5 experiments ( $F 1$ mice).

$* P<0.05$ (Student's $t$ test) compared with virgin controls in this experiment in which the spleen cells were mixed with cells from the nodes draining the site at which the emulsion of sperm adjuvant was injected. 
Some differences were observed between cells from 5 animals immunized with spermatozoa in Freund's adjuvant and cells from 4 untreated control mice (Table 1). In these experiments the leucocytes were prepared by allowing the red cells to settle out under gravity, and 4 replicate capillaries were set up for each sperm concentration as described for the experiments with $\mathrm{A} / \mathrm{J}$ mice summarized in Table 1.

\section{Discussion}

We have not found that spleen cell migration assays detected immunity to spermatozoa resulting from natural mating in mice in the way described by Dorsman et al. (1978). We found that spermatozoa strongly inhibited in-vitro migration of spleen cells from virgin and mated mice (see Table 1) and that there was no significant difference between these two groups. In addition, our observations on females immunized with spermatozoa in Freund's complete adjuvant did not provide evidence that spleen cell migration assays were particularly sensitive procedures for the detection of immunity to spermatozoa. Although the difference between immunized and control groups was statistically significant, the migration of spleen cells from the immunized females was only $10-25 \%$ less than that of the controls, and naturally inseminated spermatozoa might be expected to be less immunogenic than spermatozoa injected subcutaneously in adjuvant. The procedure also differed from that used by Dorsman et al. (1978) in that lymph node cells draining the site of injection were added to the spleen cells with the aim of increasing the sensitivity of the test. The major difference between the present observations and those of Dorsman et al. (1978) is that Dorsman et al. reported that spermatozoa caused no significant inhibition of the migration of spleen cells obtained from virgin mice even at concentrations of $20 \times 10^{6} / \mathrm{ml}$. We observed inhibition with all the procedures tried and all the mouse strains tested, which included some of those used by Dorsman et al. (1978) and Roberts \& Lewins (1979). The effect could not be attributed to the batches of fetal calf serum used because inhibition was observed even in serum-free media and in media supplemented with FCS selected for low mitogenicity. It is possible that the differences reflect differences between the mice used in the degree of immunity to environmental antigens shared with spermatozoa. A similar hypothesis has been advanced to explain the fact that some workers report the presence of "natural antibodies" to spermatozoa in the sera of untreated animals while some do not (see Johnson \& Edidin, 1972). The possibility of effects of sperm preparations on lymphocyte viability cannot, however, be excluded. The inhibition of virgin spleen cell migration by spermatozoa does not seem to be a phenomenon confined to the mice bred at Mill Hill. Similar inhibition was observed in experiments carried out with $\mathrm{A} / \mathrm{He} \mathrm{Ha}$ mice at the University of Rochester, New York (D. Duncan \& R. J. T. Hancock, unpublished). It has also been reported (Hurtenbach \& Shearer, 1982) that epididymal spermatozoa injected into syngeneic mice have immunosuppressive effects on splenic leucocytes. It is possible that the assay might be more sensitive if antigenic fractions of spermatozoa were used rather than whole spermatozoa. Ammonium sulphate-precipitated material prepared according to Freund, Thompson \& Lipton (1955) was not inhibitory at concentrations up to $100 \mu \mathrm{g} / \mathrm{ml}$ (unpublished).

Therefore, although there is evidence that the female shows some immune changes after natural mating (see 'Introduction') we have been unable to confirm that spleen cell migration assays of the types described detected immunity to spermatozoa resulting from natural mating in mice. We are examining other assays to determine their suitability for the measurement of responses to inseminated spermatozoa.

We would like to thank Allan Mowat for information on the use of leucocyte migration inhibition assays and D. W. Dresser for reading a draft of the manuscript. 


\section{References}

Alkan, S.S. (1978) Antigen-induced proliferation assay for mouse $T$ lymphocytes. Response to a monovalent antigen. Eur. J. Immunol. 8, 112-118.

Beer, A.E., Billingham, R.E. \& Scott, J.R. (1975) Immunogenetic aspects of implantation, placentation and feto-placental growth rates. Biol. Reprod. 12, 176-189.

Bendixen, G. \& Soborg, M. (1969) A leucocyte technique for in vitro detection of cellular (delayed type) hypersensitivity in man. Danish med. Bull. 16, 1-6.

Bendixen, G. \& Soborg, M. (1970) Comments on the leucocyte migration technique as an in vitro method for demonstrating cellular hypersensitivity in man. $J$. Immunol. 104, 1551-1552.

Bloom, R.R. \& Bennett, B. (1966) Mechanisms of a reaction in vitro associated with delayed-type hypersensitivity. Science, N.Y. 153, 80-82.

Dorsman, B.G., Tumboh-Oeri, A.G. \& Roberts, T.K. (1978) Detection of cell-mediated immunity to spermatozoa in mice and man by the leucocyte adherence-inhibition test. J. Reprod. Fert. 53, 277283.

Edwards, R.G. (1960) Antigenicity of rabbit semen, bull semen and egg yolk after intravaginal or intramuscular injection of female rabbits. J. Reprod. Fert. 1, 385 401.

Ferderlin, K., Maini, R.N., Russell, A.S. \& Dumonde, D.C. (1971) A micro-method for peripheral leucocyte migration in tuberculin sensitivity. J. clin. Path. 24, 533-536.

Freund, J.D., Thompson, G.E. \& Litpon, M.M. (1955) Aspermatogenesis, anaphylaxis, and cutaneous sensitization induced in the guinea pig by homologous testicular extract. J. exp. Med. 101, 591-604.

Hancock, R.J.T. (1981) Immune responses to sperm. In Oxford Reviews of Reproductive Biology, Vol. 3, pp. 182-208. Ed. C. A. Finn. Clarendon Press, Oxford.
Hughes, L., Preece, A.W. \& Light, P.A. (1980) Migration inhibition of cells from thymus and spleen as a sensitive in vitro method for detecting cell-mediated immunity in the mouse. Immunol. Lett. 1, 269-273.

Hurtenbach, U. \& Shearer, G.M. (1982) Germ cellinduced immune suppression in mice. Effect of inoculation of syngeneic spermatozoa on cell mediated immune responses. J. exp. Med. 155, 1719-1729.

Johnson, M.H. \& Edidin, M. (1972) H-2 antigens on mouse spermatozoa. Transplantation 14, 781-786.

Lengerova, A. \& Vojtiskova, M. (1963) Prolonged survival of syngeneic male skin grafts in parous C57BL mice. Folia biol., Praha 9, 72-73.

Maini, R.N., Roffe, L.M., Magrath, I.T. \& Dumonde, D.C. (1973) Standardization of the leucocyte migration test. Int. Arch. Allerg. appl. Immunol. 45, 308-321.

McLean, J.M., Shaya, E.I. \& Gibbs, A.C.C. (1980) Immune response to first mating in the female rat. $J$. reprod. Immun. 1, 285-295.

Menge, A.C. (1980) Clinical immunologic infertility: diagnostic measures, incidence of anti-sperm antibodies, fertility and mechanisms. In Immunological Aspects of Infertility and Fertility Regulation, pp. 205224. Eds D. S. Dhindsa \& G. F. B. Schumacher. Elsevier/North Holland, Amsterdam.

Prehn, R.T. (1960) Homograft tolerance induced by successive matings and implications concerning choriocarcinoma. J. natn. Canc. Inst. 25, 883-886.

Roberts, T.K. \& Lewins, E.G. (1979) Immunological recognition of spermatozoa by the female immune system following natural mating. In Proc. 4th Int. Symp. Immunology of Reproduction, Varna, pp. 482485. Eds K. Bratanov, V. H. Vulchanov, V. Dikov, R. Georgierva \& B. Somlev. Bulgarian Academy of Sciences Press, Sofia.

Received 24 January 1983 